\title{
The Effect of Brand Leadership Styles on Employees’ Brand Citizenship Behavior
}

\author{
Hasnizam Shaari ${ }^{1}$, Salniza Md. Salleh ${ }^{1} \&$ Zolkafli Hussin $^{1}$ \\ ${ }^{1}$ School of Business Management, College of Business, Universiti Utara Malaysia, Malaysia \\ Correspondence: Hasnizam Shaari, School of Business Management, College of Business, Universiti Utara \\ Malaysia, 06010 Sintok, Kedah, Malaysia. Tel: 60-4-928-7405. E-mail: zamree@uum.edu.my
}

Received: December 17, 2014

Accepted: March 2, 2015 Online Published: June 5, 2015

doi:10.5539/ass.v11n18p86

URL: http://dx.doi.org/10.5539/ass.v11n18p86

\begin{abstract}
Internal branding relatively new constructs in marketing literature. It is assumes adequate internal branding practices could enhance overall brand performance through employees' brand consistent behavior. This study conceptualized employees' brand consistent behavior as brand citizenship behavior. The main objective of this study is to examine the relationship between transactional and transformational brand leadership and brand citizenship behavior. Self-administered questionnaires were distributed to 286 respondents from 3-5 star rating hotels from northern states of Malaysia namely; Perlis, Kedah and Penang. The findings revealed that transactional and transformational brand leadership have a significant positive relationship on brand citizenship behavior. However, transformational brand leadership is more dominant in explaining brand citizenship behavior. Future research should focus on other internal branding practices as well as a new context mainly to enhance the superiority of the concept.
\end{abstract}

Keywords: internal branding, brand citizenship behavior, brand leadership

\section{Introduction}

Internal branding recognized the important roles of employees as brand sustainable competitive advantage. According to MacLaverty, McQuillan and Oddie (2007), internal branding is a set of strategic processes that align and empower employees to deliver the appropriate customer experience in a consistent fashion. It is assumed that when employee's behavior is aligned with the organization's brand values, it could minimize the discrepancies between brand promise and brand delivery (Brexendorf \& Kernstock, 2007), thus ultimately contributes to holistic customers' brand experiences and satisfaction (Burmann \& Zeplin, 2005). Therefore, in relation to internal branding, employees' behavior towards the organization's brand considered as critical success factor of overall brand performance.

In branding literatures, employees' brand behavior could be either in-role or extra role brand behavior (Burmann \& Zeplin, 2005; Morhart, Herzog, \& Tomczak, 2009). In role brand behavior is refers to the ability of employees to meet the brand standard prescribed by the organization based on their roles as brand representative while extra role refers to an employee's commitment to exhibit or involve in beyond the prescribed brand roles that enhance the organization's corporate brand performance (Morhart et al., 2009). King and Grace (2008) added that extra-role brand behavior is related to 'non-prescribed employee behavior that is consistent with the brand values of the organization'. Many literatures at the agreement that extra role found to be more meaningful for the brand survival and could become one of the differentiation tools. Burmann and Zeplin (2005) term the extra-role brand behavior as brand citizenship behavior (BCB). Brand citizenship behavior is defined as "the employees' voluntary basis to project a number of generic employee behaviors that enhance the brand identity" (Burmann \& Zeplin, 2005, p. 282). Brand citizenship behavior is a measure of the employee willingness to exert extra effort that goes beyond its basic functions i.e. projecting the brand-consistent behavior. Hence, the researchers essentially outlined the employees' brand-consistent behavior that could be a part of 'living the brand' as proposed by Ind (2001).

However, it is assumed that employees commit to the organization's brand only if their management demonstrates that their behaviors are also consistent with the brand values. In order for internal branding to succeed in the organization, a leader should understand, support, and consistently commit to the internal branding process (Vallaster \& de Chernatony, 2006). Corporate Leadership Council (2004) also indicated all 
activities of leaders (such as encourages and manages innovation, respects employees as individuals, demonstrates passion to succeed, open to new ideas) that drive employees' effort towards organization's performance is at $26 \%$. Thus, it is indicates for the room for improvement with regard to the relationship between leaders and followers. Social Learning Theory (Bandura, 1977) argues that people learn new attitude and behavior by observing other's behavior. This is supported by the research finding of Thorbjornsen and Supphellen (2011), who conducted a study among 112 employees of Scandinavian's bank that highlighted the importance of leader/superordinate role model in influencing brand-consistent behavior. In addition, Burmann et al. (2008) agree that brand leadership is one of the key determinants of brand commitment that ultimately influences BCB.

Leadership styles such as transformational and transactional leadership are also found to be significant in contributing to the employees' behavior performance. However, the leadership styles thus far have been studied to affect macro-level performance i.e. organization where the measurement items have exclusively focused on the management leadership style in general. In dealing with $\mathrm{BCB}$, the leadership style needs to be geared towards brand-related leadership. Consequently, management should behave consistently with the brand values to achieve appropriate behaviors from employees. Yet, there is no empirical evidence to support the argument. This notion is derived based on Burmann \& Zeplin (2005) overview of how difference type of leadership practices had influence employees' BCB. Hence, the objective of this study is to examine the relationship between leadership style and brand citizenship behavior. For the purpose of the study, the leadership style is termed as brand leadership, which is based on the brand-centric perspective.

\section{Literature Review}

\subsection{The Concept of Brand Leadership}

Within the field of organizational behavior, leadership is considered one of the most prominent factors in influencing behaviors of the organizational members (i.e. employees) toward the accomplishment of organizational performance, Evidently, much is known on how leadership style influences employees' behavior specifically on the job and organizational performance (e.g. Bass, 1990; McColl-Kennedy \& Anderson, 2002). In relation to the corporate branding studies, however, little is known on how leadership style influences employees' brand behaviors. But researchers (e.g. Burmann et al., 2008; Goom, MacLaverty, McQuillan, \& Oddie, 2008; Kimpakorn \& Dimmit, 2007; Morhart et al., 2009; Solnet, 2006; Vallaster \& de Chernatony, 2006) have highlighted the role of organizational leaders (especially top management and supervisors) as influential predictors of employees' brand attitude and behaviors.

Leader-member exchange studies have helped expand the field of internal branding. For instance, the work of Vallaster and de Chernatony (2006) revealed that leadership influences brand commitment and consequently brand-supportive behaviors, by acting as a role model and communicating consistently the brand values. However, these researchers did not discuss the specific types of leadership that might influence such behavior but limited to studying the relationship between employees and leaders that took place during the process of internalization.

The earlier qualitative work of Vallaster and de Chernatony (2004), however, found indicators of internal branding success. In a study among 25 middle and top managers of multiple organization brands in Austria and Germany, they revealed the relevance of a leader in internal brand building. Leaders are found to be the mediator to the relationship between corporate branding structures and individuals. According to these researchers, leaders may exhibit their leadership through verbal communication and social interactive behavior (such as showing commitment, living the brand promise, trusting and enabling employees to fulfill customers' need) that later influence the brand success.

The concept of brand leadership is first introduced by Morhart et al. (2009). Similar to the commonly accepted leadership style in management studies (e.g. Bass, 1990), Morhart and his colleagues suggested that brand centric leadership style can be divided by two, namely;

- Brand-specific Transactional Leadership (BTSL)

Brand-specific transactional leadership is defined as 'a leader's approach to motivate his or her followers to act on behalf of the corporate brand by emphasizing a contingency rationale in follower's minds'

- Brand-specific Transformational Leadership (BTFL)

Brand-specific transformational leadership iserred to as 'a leader's approach to motivate his or her followers to act on behalf of the corporate brand by appealing to their values and personal conviction'. 
These two types of brand leadership styles also contribute to organizational performance, similar to the traditional leadership style. For instance, transformational brand leadership is postulated to be able to stimulate extra-role brand behavior (i.e. BCB) while transactional brand leadership, which stresses the social exchange process, will only generate in-role brand behavior (Burmann et al., 2008; Morhart et al., 2009). This is also consistent with the findings in organizational behavior studies (e.g. Bass, 1990; Podsakoff, MacKeinzie, Moorman, \& Fetter, 1990).

\subsection{The Relationship between Brand Leadership and BCB}

The earlier studies in internal branding attempt to investigate the influence of leader in stimulating employees' brand-consistent behavior. It is assume that employees would only commit to organizations' objective and goal only if their management shows an exemplar behavior. For instance, research findings of Thomson, Chernatony, Arganbright and Khan (1999) state that employees brand commitment and their willingness to become brand champions is subject to their confidence in organization's leadership. The findings revealed that only $15 \%$ of the respondents strongly agree that they have believed in their leaders. The remaining respondents seem not to agree and found that leadership practice is lacking thus limit their emotional buy-in as well as their readiness to live the brand such as in displaying helping behavior and make brand recommendation to others. This is harmful to the brand as the database by Market \& Opinion Research International [MORI] (1997) stated one in every five employees are 'brand saboteurs' which disseminate negative brand word-of-mouth to public. Hence, management should at least minimize the numbers and turn those employees to become close to 'brand champions' category (Ind, 2001; Thomson et al., 1999). Therefore, management in a capacity as a leader, also need to check and balance what are the exemplar behaviors to display during their interaction with internal customers (i.e. employees), mainly to influence employees' brand behaviors.

Previous studies found supported that brand leadership would influence employees' brand attitude and behavior. For instance, Vallaster and de Chernatony (2004) in arguing how much leaders matter in internal brand building propose that leadership need to coordinate corporate branding structure and individual brand-adequate behavior. This is to enable leaders to shape and be shaped by others (i.e. followers). The researchers further asserted that leaders need to support employees in shaping their behavior towards the brand. This could be done through verbal and non-verbal communication behavior (i.e. social interactive behavior). Social interactive behavior is also in line with transformational leadership styles as suggested by Morhart et al. (2009). For instance, Vallaster and de Chernatony suggested that leaders involved in social interactive when they show commitment (i.e. similar to role model and charismatic), lives the brand promise (i.e. similar to arousing personal involvement and provide inspiration), and trusts and enables his/her employees to perform their role (i.e. similar to rethink their jobs and promote intellectual stimulation). Although several researchers (e.g. Goom et al., 2007; Kimpakorn \& Dimmit, 2007; Solnet, 2006) have highlighted the importance of leadership in brand building behavior, they limit their studies to identifying the validity of leaders/leadership practice in internal branding without clearly identifying and differentiating the specific leadership style that is appropriate in explaining employees' brand behavior. Therefore, transactional brand leadership and transformational brand leadership is proposed to influence employee's brand commitment and behavior.

Burmann and Zeplin (2005) highlight the urgency of leadership in stimulating employees' brand commitment and behavior. Their conceptual papers concerning behavioral approach to internal brand management identified brand leadership at two main level namely; macro level (include executive board and Chief Executive Officer) and micro level (executive). Their finding revealed that leaders at all level (i.e. macro and micro level) need to support internal branding by words and actions and became the role model for the brand (Burmann \& Zeplin, 2005). The scholars also come to conclusion that transformational leadership approach is best in enticing employees' BCBs. Yet, there is no empirical evidence to support the argument. This notion is derived based on these researchers overview of how different type of leadership practices had influence employees' OCB.

Recent findings of Burmann et al. (2008) also did not systematically check the influence of different type of leadership practices (namely transformational and transactional leadership) on employees' brand commitment and BCBs. The study indicated that brand leadership positively influence brand commitment and BCBs (namely helping behavior, brand enthusiasm and brand development). Hence, it is important to examine how different types of brand leadership (i.e. transactional and transformational) influence employees' brand commitment and BCBs.

To date, the only brand-centric leadership measure is explored by Morhart et al. (2009). These researchers attempt to investigate how different types of brand leadership namely transactional brand leadership and transformational brand leadership influence employees' 'in-role brand behavior' and 'extra-role brand behavior'. 
This study was embarked to frontline employees telecommunication with two folds objectives; (1) what types of leadership influence employees' brand building behavior, and (2) whether transformational brand leadership could be learn by managers. A total of 269 frontline employees were involved in study 1 and 222 managers involved in study 2 .

The findings revealed that brand specific transformational leadership is more effective in enhancing brand building behaviors among followers than to brand-specific transactional leadership. The result is consistent with leadership theory that suggests transformational leadership is superior to transactional leadership (Bass, 1990; Burmann et al., 2008).

Based on the preceding discussion, it is hypothesized that;

H1: Transactional brand leadership has a significant relationship on brand citizenship behavior.

H2: Transformational brand leadership has a significant relationship on brand citizenship behavior.

Thus, theoretical framework is shown as in the following Figure 1.

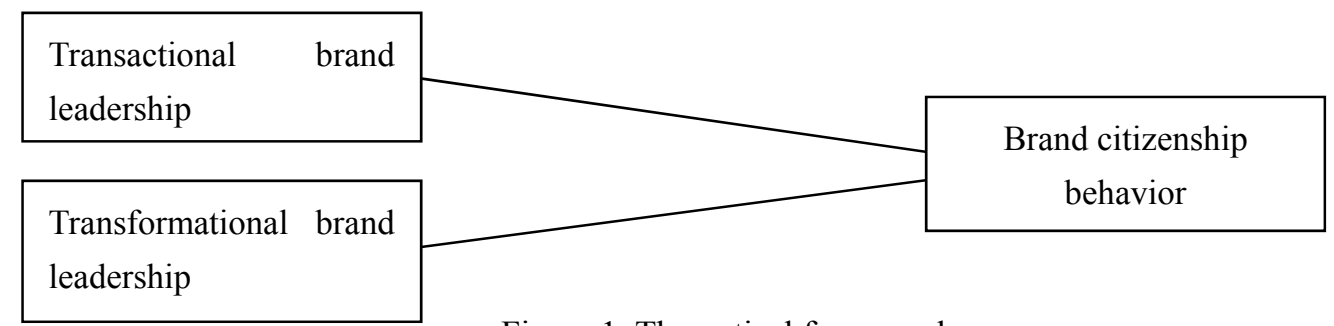

Figure 1. Theoretical framework

\section{Methodology}

This study employed quantitative approach and cross-sectional in nature. A total of 12 hotels in northern region of Peninsular Malaysia were participated in this study, namely, 1 hotel in Perlis, 5 in Kedah and 6 in Penang. A total of 435 sets of questionnaire were distributed. However, only 314 sets of questionnaire were returned. As such the response rate is $72.2 \%$ which is considered as high. However, only 286 were proceed for data analysis. A total of 26 sets of questionnaire were considered as damage and/or incomplete.

Both frontline and backstage employees from three to five star hotels were included in this study because in advance service economy, both are equally important for the brand success (Burmann et al., 2008). The questionnaires were randomly distributed to the identified employees with the assistance of Human Resource Department's officer. For the purpose of the study, the original brand citizenship behaviors measure as proposed by Burmann et al. (2008) is used while measure of brand leadership was adapted from Morhart et al. (2009). All measurement items mainly in 6-point Likert Scale from 1 for 'strongly disagree' to 6 for 'strongly agree'.

\section{Findings}

\subsection{Respondents Profile}

In general, the respondents were from three $(40.7 \%)$, four $(47.7 \%)$ and five star hotel $(11.6 \%)$. The distribution between frontlines and backstage employees is $60 \%$ to $40 \%$ that conform with the nature of hotel industry. Based on the survey almost $65 \%$ of the respondents are permanent workers with at least attached 1 to 3 years to particular hotel. Most of the respondents (about 62\%) gained at least secondary school academic qualification. $47.2 \%$ of the respondents earned between RM501 to RM1000 monthly. The distribution of gender is equally distributed between male and female i.e. $46 \%$ and $54 \%$ respectively. About $52 \%$ aged between 21 to 30 years old, $34 \%$ aged 31 to 40 years and $11 \%$ aged more than 40 years.

\subsection{Correlation Analysis}

The following Table 1 summarized the finding of correlation analysis.

Table 1. Pearson's Correlation between measure of brand leadership styles and brand citizenship behavior

\begin{tabular}{llll}
\hline Scale & $\mathbf{1}$ & $\mathbf{2}$ & $\mathbf{3}$ \\
\hline Transactional brand leadership & 1 & $.769^{* *}$ & $.626^{* *}$ \\
Transformational brand leadership & - & 1 & $.712^{* *}$ \\
Brand citizenship behavior & - & - & 1 \\
\hline
\end{tabular}


Based on the Table 1, the relationship between leadership styles and brand citizenship behavior was investigated using Pearson product-moment correlation coefficient. Based on the findings, there was a strong, positive correlation between different leadership styles and brand citizenship behavior. The strength of relationship between transactional brand leadership was $\mathrm{r}=.626$, while for transformational brand leadership was $\mathrm{r}=.712, \mathrm{n}$ $=286, \mathrm{p}<.001$. According to Cohen (1988), coefficient value greater than .5 indicates the strong relationship between the tested variables.

\subsection{Regression Analysis}

Regression analysis was conducted mainly to answer the main hypotheses of this study. Assumptions of regression were assessed and no serious violations were identified. Tolerance value is .408 and variance inflation factor (VIF) is 2.45 show no issues of multicollinearity. Linearity was assessed through analysis of residuals and partial regression plots. To show linearity, residuals scatter plot was used to ensure that they are roughly rectangularly distributed with most of the plots distributed at the center. Scatter plot was also used to address the issue of homoscedasticity. In essence, residuals and scatter plot should not show any trend of increasing or decreasing residuals to indicate that the assumption of homoscedasticity is not violated. Normality was checked by examining the histogram of the residuals and the normal probability plot. Normal distribution should indicate a residual line that closely follows the straight diagonal that is shown in the plot. In order to assess the independence of error terms, the Durbin-Watson statistics were used. In line with Coakes and Steed (2003), independence of error terms are not violated if the value of Durbin-Watson ranges from 1.50 to 2.50.

The following Table 2 summarized the result of regression analysis.

Table 2. Regression analysis result

\begin{tabular}{cc}
\hline & $\begin{array}{c}\text { Dependent Variable } \\
\text { Brand Citizenship Behavior }\end{array}$ \\
\hline Independent Variables: & $.192^{* *}$ \\
Transactional brand leadership & $.564 * *$ \\
Transformational brand leadership & 154.525 \\
$F$ Value & .522 \\
$R^{2}$ & .519 \\
Adjusted $R^{2}$ & 1.865 \\
Durbin-Watson &
\end{tabular}

Table 2 shows that all the hypothesized relationships were significant. Transactional brand leadership $(\beta=.192$, $\mathrm{p}<.01)$ and transformational brand leadership $(\beta=.564, \mathrm{p}<.01)$ were found to have significant and positive relationships to $\mathrm{BCB}$. Overall, the variance explained by the set of predictors is $52.2 \%$. Hence, hypothesis H1 and $\mathrm{H} 2$ were supported.

\section{Discussion and Recommendation}

The findings suggest that hotel employees learned their attitude and behavior through exemplar behaviors of their leader. This is inline with the findings of Burmann et al. (2008), Morhart et al. (2009), Thorbjornsen and Supphellen (2011), Vallaster and de Chernatony (2006) that persistently argued the importance of brand leadership in encouraging employees' brand-consistent behavior such as BCB. The existence of leaders' support especially as role model, arousing personal involvement and pride as well as teaching and coaching would also stimulate employees' BCB.

The huge variance explained by the predictors also indicate that it seems truism as employees' willingness to become brand champions is subject to their confidence in their leaders' leadership. In certain cases, whereby employees perceived that brand leadership practice is lacking, it will deter employees' psychological attachment and their willingness to live the brand (Thomson et al., 1999).

Morhart et al. (2009) proposed that transformational brand leadership influences more in-role brand behavior and extra-role brand behavior than transactional brand leadership. The present study found support for this proposition. However, transformational brand leadership was found to be more influential in eliciting $\mathrm{BCB}$. Thus, the findings also consistent with Burmann et al.'s early assumption that similar to OCB, transformational brand leadership would be more influential in predicting employees' BCB. 
In this study, transformational leadership contains element of directive (similar to teaching and coaching) and participative (similar to arousing personal involvement). Beside, hotels operation and employees involve much of routine and structured jobs such as reservation taking, guest checking in and checking out, as well as housekeeping. In hotel operation, although the nature of the job is routine and structured, consumers' behavior during the service contact is very unpredictable thus demand employees to be prepared and creatively solved the consumers' unique problem. Essentially, employees just need more freedom and empowerment in delivering the brand promise without tarnishing their organization's brand image.

\section{Conclusion}

This study revealed that brand leadership is paramount important for employees to display brand citizenship behavior. However, transactional brand leadership plays a small function in explaining the effect of overall brand leadership on brand citizenship behavior as compared to transformational brand leadership. Using this sample, it is proven that transformational leadership approach is best in enticing employees' BCBs.

This study contributed to extend the boundary of knowledge that different leadership style would influence BCB differently. Based on the findings, transformational brand leadership is found to be more meaningful in stimulating employees' BCB as compared to transactional brand leadership. The findings could fulfill the gaps as identified by Burmann et al (2008) that similar to OCB, transformational brand leadership is more prominent in encouraging employees to exhibits BCB. Based on the findings, practically, hotel managers or leaders should display consistent brand behaviors. Leaders should behave as a role models for their followers. Leaders should authentically 'living' the brand values. As proposed by Morhart el al. (2009), leaders also should arouse personal involvement and instill pride towards the organization's (i.e. hotels) brand. As far as transformational brand leadership concerns, leaders also required to empower and help their followers (employees) to understand the corporate brand promise and values and their implications of their work performance. This is consistent with Arruda (2013) which highlighted that employees need to feel connected and understand their corporate brand to 'live' the brand. More important, managers should teach and coach their employees to become as a brand ambassador. Beside, managers also could consider to offer rewards when their employees had achieved several role-expectations from the management as a part of the transactional brand leadership's component.

This study limit to understand the effect on one of the internal branding practices only. Future research should focus on other determinants. This study also specifically focus on the hotel industry and perhaps other business setting could be considered mainly to enhance the superiority of the concept of internal branding and brand citizenship behavior.

\section{References}

Arruda, W. (2013). Three steps for transforming employees into brand ambassadors. Forbes. Retrieved from http://www.forbes.com/sites/williamarruda/2013/10/08/three-steps-for-transforming-employees-into-brandambassadors/

Bandura, A. (1977). Social learning theory. Eaglewood Cliffs, NJ: Prentice Hall.

Bass, B. M. (1990). From transactional to transformational leadership: Learning to share the vision. Organizational Dynamics, Winter, 19-31.

Brexendorf, T. O., \& Kernstock, J. (2007). Corporate behavior vs. brand behavior: Towards an integrated view? Brand Management, 15(1), 32-40.

Burmann, C., \& Zeplin, S. (2005). Building brand commitment: A behavioral approach to internal brand management. Brand Management, 12(4), 279-300. http://dx.doi.org/10.1057/palgrave.bm.2540223

Burmann, C., Zeplin, S., \& Riley, N. (2008). Key determinants of internal brand management success: An exploratory empirical analysis. Brand Management, 21(1), 1-19. http://dx.doi.org/10.1057/bm.2008.6

Coakes, S. J., \& Steed, L. G. (2003). SPSS version 11.0 for Windows: Analysis without anguish. Milton, Qld: John Wiley \& Sons Australia.

Cohen, J. W. (1988). Statistical power analysis for behavioral sciences (2nd ed.). Hillsdale, NJ: Lawrence Erlbaum Associates.

Corporate Leadership Council. (2004). Driving performance and retention through employee engagement. Corporate Executive Board. Retrieved from http://www.usc.edu/programs/cwfl/assets/pdf/Employee\% 20engagement.pdf

Goom, S., MacLaverty, N., McQuillan, P., \& Oddie, H. (2008). Internal branding: A human resources 
perspective. Canadian Marketing Association. Retrieved from http://www.the-cma.org/?WCE $=\mathrm{C}=62 \%$ $7 \mathrm{CK}=228572$

Ind, N. (2001). Living the brand: How to transform every member of your organization into a brand champion. London: Kogan Page.

Kimpakorn, N., \& Dimmitt, N. (2007). Employer branding: The perspective of hotel management in the Thai luxury hotel industry. Australasia Marketing Journal, 15(3), 49-68. http://dx.doi.org/10.1057/palgrave. bm. 2550140

King, C., \& Grace, D. (2008). Internal branding: exploring the employee's perspective. Journal of Brand Management, 15, 358-372. http://dx.doi.org/10.1057/palgrave.bm.2550136

Maclaverty, N., McQuillan, P., \& Oddie, H. (2007). Internal branding best practices study. Canadian Marketing Association. Retrieved December 2, 2008, from www.brand-matters.com/BrandNews/downloads/Internal BrandingJune07.pdf -

McColl-Kennedy, J. R., \& Anderson, R. D. (2002). Impact of leadership style and emotions on subordinate performance. The Leadership Quarterly, 13(5), 545-559.

Morhart, F. M., Herzog, W., \& Tomczak, T. (2009). Brand-specific leadership: Turning employees into brand champions. Journal of Marketing, 73, 122-142. http://dx.doi.org/10.1509/jmkg.73.5.122

Podsakoff, P. M., MacKeinzie, S. B., Moorman, R. H., \& Fetter, R. (1990). Transformational leader behaviors and their effects on followers, trust in leader, satisfaction and organizational citizenship behaviors. The Leadership Quarterly, 1(2), 107-142. http://dx.doi.org/10.1016/1048-9843(90)90009-7

Solnet, D. (2006). Introducing employee social identification to customer satisfaction research: A hotel industry study. Managing Service Quality, 16(6), 575-594. http://dx.doi.org/10.1108/09604520610711918

Thomson, K., de Chernatony, L., Arganbright, L., \& Khan, S. (1999). The buy-in benchmark: how staff understanding and commitment impact brand and business performance. Journal of Marketing Management, 15(8), 819-835. http://dx.doi.org/10.1362/026725799784772684

Thorbjornsen, H., \& Supphellen, M. (2011). Determinants of core value behavior in service brands. Journal of Service Marketing, 25(1), 68-76. http://dx.doi.org/10.1108/08876041111107078

Vallaster, C., \& de Chernatony, L. (2004). How much do leaders matter in internal brand building? An international perspective. Scandinavian Academy of Management and the International Federation of Scholarly Associations of Management 7th World Congress, Goteborg.

Vallaster, C., \& de Chernatony, L. (2006). Internal branding and structuration: The role of leadership. European Journal of Marketing, 40(7/8), 761-784. http://dx.doi.org/10.1108/03090560610669982

\section{Copyrights}

Copyright for this article is retained by the author(s), with first publication rights granted to the journal.

This is an open-access article distributed under the terms and conditions of the Creative Commons Attribution license (http://creativecommons.org/licenses/by/3.0/). 